\title{
HISTORI FILANTROPI: TINJAUAN TEORI POSTMODERN
}

\author{
Aris Puji Purwatiningsih \\ Universitas Islam Negeri (UIN) Walisongo Semarang \\ Hendri Hermawan Adinugraha \\ Universitas Dian Nuswantoro \\ e-mail: aris.puji.@gmail.com
}

\begin{abstract}
Postmodern is a breeding effort, epistemological innovation, so anthropology becomes more adaptive and productive. This can be demonstrated through the application of his theory in practice and philanthropy models. This paper aims to describe the history of philanthropy in terms of the perspective of postmodern theory. The results of the literature review indicate that at first the emergence of the philanthropy movement was the way of the rulers of the time to maintain the stability of public security by providing assistance to the community, but in the postmodern period turned into nonprofit social institutions or institutions that serve as mediators of donors to the needy. Philanthropy, initially only in the form of goods aimed at relieving and meeting the needs of a deficient society, in the postmodern era can develop into donor body parts, smiles and even empathy can be referred to as philanthropy. Alms that were originally human goods, the postmodern expanded that spread the science, moving the masses can also be called philanthropy.
\end{abstract}

Keywords: philanthropy, help, charity and postmodern. 


\section{Aris Puji \& Hendri}

\section{Pendahuluan}

Kehidupan manusia tidak bisa dilepaskan dari pergeseran era dan zaman. Perubahan demi perubahan telah terjadi dan dialami oleh realitas pengetahuan manusia. Sejak zaman kuno, pertengahan, modern dan posmodernisme pemikiran manusia memiliki karakteristiknya masingmasing. Pada setiap periode memiliki kecenderungan yang berbeda-beda sesuai dengan dialektika nalar yang dikembangkan oleh manusia dalam menghadapi realitasnya. Istilah postmodern muncul pertama kali di wilayah seni dan digunakan oleh Frederico de Onis tahun 1930-an untuk merespons seni modern. Gaumnya semakin luas terdengar setelah tahun 1960/1970-an yakni dalam cakupan bidangbidang seni rupa, arsitektur, politik, sastra, feminism, filsafat, psikologi, sosiologi dan juga secara terbatas terlintas dalam antropologi.

Pengertian postmodern memiliki perbedaan satu dengan yang lainnya sehingga istilah postmodern tidak mungkin didefinisikan dalam satu definisi tunggal dan ketat. Richard Appignanesi dan Chris Garratt memperlihatkan bahwa pengertian postmodern di antara para pemikir tampak berbeda-beda. Ada yang menggunakannya sebagai "hasil dari modernisme", "akibat dari modernisme", "anak modernisme", "perkembangan dari modernisme" dan ada yang menggunakan sebagai "konter terhadap modernisme (penolakan atas modernisme)".

Para postmodern sendiri umumnya tidak suka dengan penyeragaman dan tidak suka pula pada definisi atau pembatasan, tetapi lebih suka menerima perbedaan. Penekanan pada perbedaan (difference sebagai salah satu kata kuncinya), keberagaman, anti-esensialisme merupakan watak yang membedakannya dengan cara berpikir yang mengutamakan universalitas, kesatuan dan esensialitas yang sangat dominan pada paradigma sebelumnya (paradigma 
modern). Dalam perkembangannya, terdapat dua golongan ekstrim dalam memahami postmodern yaitu (Lubis, 2004, 75):

1) Pertama, para pemikir yang bersikap moderat, yang memandang bahwa postmodern adalah lanjutan saja dari modern. Pemikir-pemikir yang berada dalam ranah pemikiran seperti itu di antaranya seperti: Daniel Bell (memberinya istilah: "post-industri"), Anthony Giddens memberi istilah: era modernisme radikal, the lastmodern, high modernity (Giddens, 1984), dan Jurgen Habermas menyebutnya: "postpencerahan" atau "lanjutan dari pencerahan". Berdasarkan pemahaman seperti itu, bahwa pendekatan postmodern dengan demikian bukanlah penghapusan atas segala hal yang berbau modern dan bukan pula gerakan yang mau kembali ke masa lalu. Postmodern, masih bisa memanfaatkan hal-hal yang dianggap baik pada era modern (re-use) dan penyusunan kembali potongan-potongan (collage) dari unsur-unsur tradisional dan modern serta mendaur ulang dalam konteks yang baru. Hal ini paling jelas terlihat dalam seni rupa, arsitektur, rancangan busana postmodern.

2) Kedua, adalah pandangan yang bersifat ekstrim yang memahami peralihan dari modern ke postmodern tersebut adalah perubahan paradigma yang radikal dan bukan sekadar lanjutan saja. Penganut pemikiran ini salah satunya misalnya Francois Lyotard yang berpandangan bahwa tidak adanya kelanjutan (diskontinuitas) paradigma berpikir darikedua era itu. Menurutnya, postmodern adalah era ketidakpercayaan pada narasi besar atau meta narasi dan digantikan dengan narasi kecil.

Oleh karena itu tidak heran jika Khun pernah berkata: New paradigms, give us new ways ofseeing the world, new ways of 


\section{Aris Puji \& Hendri}

thingking, and new goals and methods for investigatingnature (paradigma baru memberi kita cara-cara baru dalam melihat dunia, cara-cara baru dalam berpikir, serta tujuan dan metode-metode baru dalam mengkajialam semesta). Selanjutnya Khun menandaskan bahwa, sebuah paradigma baru perlu membuang paradigm lama, bukan cuma sekadar sebuah pengembangan terhadap teori-teori sebelumnya. Karena itu revolusi saintifik meniscayakan penolakan terhadap paradigma lama, bukan cuma sekadar penambahan. Akan tetapi merupakan perubahan secara radikal, yang satu mematikan yang lain (Zaprulkhan, 2015: 87).

Berkaitan dengan postmodernisme mengandung sejumlah konseptualisasi yang kompleks. Oleh karana itu, kajian mengenai teori postmodern dalam antropologi dan aplikasinya dalam filantropi kiranya layak untuk dikaji lebih mendalam untuk lebih memberikan deskripsi yang gamblang mengenai kajian tersebut.

\section{Pembahasan}

\section{Pengertian teori Postmodern}

Post-modernist dan post-struktualist adalah dua istilah yang identik. Pauline Rosenau memberikan klue perbedaan utama dua istilah ini dari substansinya. Post-modernist (penganut post-modernisme) lebih berorientasi terhadap kritik budaya sehingga lebih luas cakupannya, sedangkan kaum post-struktural lebih menekankan pada metode dan masalah epistemologi, seperti dekonstruksi, bahasa, wacana, makna, dan simbol (Rosenau, 1992: 3). Berikut ini ialah diskursus mengenai postmodernisme menurut para ahli:

1) Postmodern menurut Bauman, kebudayaan postmodern itu bermacam-macam, tergantung interpretasi dan penyampaian media (Bauman, 1997: 
31). Pada mulanya, modernism adalah label yang mempunyai nilai dalam seni, arsitek, tata kota, politik, teologi, adat dan budaya, dan lain-lain. Bauman menginginkan kejelasan mengenai postmodern, karena menurut Bauman, dalam segala bidang dalam postmodernisme belum ada kejelasan, maka perlu ada pemurnian konsep tentang modernism. Postmodernisme lahir dari orang-orang yang memiliki ide yang unik (aneh) yang berbeda pada masanya yang bisa mengubah segalanya. Menurut Bauman dalam postmodernisme diperlukan pihak-pihak yang memiliki kewenangan untuk memberikan kejelasan tentang postmodernisme.

2) Menurut Habermas dalam Tom Turner "City as Landscape a Post Post-Modern", modernism adalah pemikiran bahwa agama dan tradisi tidak selalu mengatur kehidupan, namun hal ini bisa dilakukan melalui filsafat dan politik. Masih menurut Habermas, modern-art kebanyakan dipakai untuk karya seni di abad ke-20, namun hanya sedikit orang yang bisa menikmatinya.

3) Lloyd dalam Tom Turner "City as Landscape a Post PostModern", menjelaskan bahwa postmodern adalah memutus total teori dan kultur modern karena kegagalan modern theory dalam melihat realitas dan paradigma yang ada saat ini. Postmodern theory tidak membicarakan sesuatu yang baku dalam benar atau salah, semua bisa lebih terbuka. Misalnya modern arsitektur adalah sebutan untuk karya arsitek mulai abad ke-20, modern planning adalah ide untuk membuat suatu kota menjadi lebih baik, lebih sehat, dan lebih multifungsi mulai abad ke-19. Semua teori postmodernisme mengiginkan sesuatu yang lebih dari modernism (Turner, 1996: 3). 


\section{Aris Puji \& Hendri}

Menurut teori postmodernisme, antropologi sebenarnya dalam kondisi krisis karena baru berhasil mempelajari suatu kelompok masyarkat dan kebudayaannya, namun belum menjangkau pemikiran dalam kelompok masyarakat ini, oleh karena itu postmodern datang dengan tujuan mempopulerkan cara pikir baru ini ke dalam antropologi (Gardner dan Lewis, tt: 23). Sedangkan menurut Antropolog muslim bernama Akbar S. Ahmed, bahwa postmodern didalamnya tercakup esai-esai pemikiran baru. Di antara yang penting seperti:

1) Menjelajahi pemikiran postmodern menandai adanya keraguan dan ketidakpercayaan terhadap proyek modernitas yang dibangun di atas fondasi pemikiran yang mengedepankan totalitas universal. Postmodern membutuhkan pemahaman wawasan makna bukan model berpikir hitam putih;

2) Berkembang pesatnya teknologi tinggi informasi (cyberpace) menjadi instrument yang kuat dalam memproyeksikan kultur dominan dari peradaban global dewasa ini. Oleh Amerika Serikat misalnya, telah menjadikan teknologi informasi berskala tinggi tersebut sebagai media penyebar berkembang biaknya virus-virus kapitalis hegemoni (dominan) dalam semua lini sisi kehidupan masyarakat di dunia ini.

3) Tokoh-tokoh postmodern lebih sebagai filsuf daripada seorang Antropolog (etnograf), karena pada dasarnya tugas postmodern lebih menyasar pada persoalan pragmentasi ide-ide sosial-politik dan perubahan pemikiran (Lubis, 2014: 75).

Menurut Ahimsa Putra dan Heddy Shri (2005), arus pemikiran postmodern dalam antropologi budaya, dapat dikatakan sebagai sebuah arus pemikiran yang berusaha untuk lebih jujur terhadap diri sendiri dan lebih berani menerima kenyataan sekaligus tuduhan bahwa etnografi adalah fiksi. Namun dengan sikap ini pula, para penulis 
etnografi yang mengikuti arus pemikiran postmodern, menjadi lebih mampu memanfaatkan sarana yang mereka gunakan dalam menyampaikan ide dan pesan mereka, yakni penulisan dan retorika. Arus pemikiran postmodern dalam antropologi budaya, dengan perenungannya yang lebih dalam dan kritis mengenai kemampuan dan keterbatasan retorik dalam proses penulisan etnografi, serta perhatian yang lebih serius terhadap proses representasi, menampilkan suatu kebudayaan (Harbaugh, 1998: 269). Salah satu contohnya ialah praktik dan model filantropi dalam budaya Islam yang diharapkan akan mampu memanfaatkan retorik tersebut untuk mencapai tujuan yang diinginkan, yakni melancarkan dan sekaligus meluncurkan kritik kebudayaan melalui retorik yang dianggap paling efektif.

\section{Sejarah munculnya teori Postmodernisme}

Revolusi Perancis adalah salah satu contoh postmodernisme yang bisa dilihat dari lambang, semboyan, tata kelola kota dan industri, yang merupakan ciri khas dari postmodernisme. Post-modernisme dalam arsitek dimulai setelah masa modern (Gardner dan Lewis, tt: 7). Postmodernismetheory bercirikan bahasa, karena latar belakang munculnya teori ini adalah proses sejarah. Sebuah proses sejarah agar bisa dibaca harus disampaiakan melalaui bahasa, postmodern adalah interpretasi sejarah yang tidak berkembang, sehingga teori ini tidak dibutuhkan lagi karena manusia adalah makhluk yang dinamis. Postmodern theory adalah teori hasil filosof dan scintist sekitar tahun 1970-an yang mencoba mengimpresi orang-orang Perancis yang pada saat itu yang didonminasi oleh sifat egoism (Hearn, 2006: 1).

Postmodern theory banyak digunakan sejak tahun 1950an dalam berbagai bidang sehingga menimbulkan banyak problem, semua bidang tersebut. Sebagai contoh melihat fenomena jins levis dengan teori postmodern, setelah ditelaah lebih jauh malah akan menimbulkan banyak pergeseran 


\section{Aris Puji \& Hendri}

makna, karena berawal dari definisi kebahasaan (linguistic), sedangkan bahasa dari wkatu ke waktu akan memiliki term yang berbeda. Kipas angin jika dilihat dengan teori postmodern adalah sebuah benda yang warnanya tertentu yang bisa mengeluarkan angin, tanpa menyebutkan dengan detail cara kerjanya. Definisi seperti ini kurang disukai orangorang Barat karena tidak bisa mengungkap sisi artistiknya (Bertens, 1995: 13).

Olson (dalam Bertens, 2005) menjelaskan pada tahun 1970 memakai pemikiran Heidegger dan tulisan Derrida tentang Heidegger, mengevolusi postmodern theory, yaitu menjadikan postmodern lebih sesuai dengan ruang dan waktu karena terpengaruh pemikiran hermeneutic Derrida. Pada awal munculnya postmodern theory sekitar tahun 1960an, awalnya aplikasi teori ini sangat kaku dan tidak artistik sehingga malah bisa merusak tata nilai dan definisi benda itu sendiri. Namun sejak tahun 1980-an, Olson menggunakan hermeneutika Heidegger dan Derrida sehingga menjadikan definisi lebih luwes dan sesuai ruang \& waktu saat ini (Bertens, 1995: 13).

Samuel Beckett, Vladimir Nabokov, John Barth, Donald Barthelme mengkritik teori postmodern paada tahun 1960-1970 adalah teori yang aneh, yang radikal. Sally Banes juga mengkritik postmodern dalam tarian (dance). Maureen Turim's juga mengkritik postmodern dalam periodisasi film yang menurut Maureen Turim's adalah: film-primitive (18951906), klasik awal (1906-1925), era klasik (1925-1955), era modern (1955-1975) dan era postmodern (1975 sampai sekarang). For Douglas Crimp, Abigail Solomon-Godeau dalam fotografi juga mengkritik postmodern theory. Menurut mereka, postmodern adalah masa akhir 1970-an sampai awal tahun 1980-an. Pertentangan yang lain menurut Bartens bahwa postmodern malah merusak tatanan nilai yang sudah ada, pendefinisian postmodern terlalu radikal 
dari budaya yang sudah ada. Menurut Derrida, postmodern terlalu bebas, sehingga tidak bisa mewakili semuanya.

Howe's (1959) mengatakan bahwa postmodern dalam tulisan para penganut postmodern yaitu: Saul Bellow, Norman Mailer, J.D. Salinger, Bernard Malamud itu kurang jujur. Karena teori tersebut merupakan teori yang kurang terbuka, karyanya "tanggung", seperti ada sesuatu yang disembunyikan (Samuel Beckett, Vladimir Nabokov, John Barth, Donald Barthelme dalam Vance Bourjaily, 1982).

Beberapa kecenderungan umum yang mendasari gerakan postmodernisme yang bisa dianggap sebagai kerangka konseptualisasi, muculnya gerakan postmodernisme adalah persoalan-persoalan yang menyangkut hal-hal sebagai berikut:

1) Pertama, segala "realitas" adalah konstruksi semiotis, artifisial dan ideologis.

2) Kedua, sikap skeptis dan kritis diri terhadap segala bentuk keyakinan tentang 'substansi'.

3) Ketiga, realitas bisa ditangkap dengan banyak cara (pluralisme).

4) Keempat, segala sistem konotasi otonom dan tertutup, diganti dengan jaringan, relasionalitas ataupun proses yang senantiasa saling-silang dan bergerak dinamis.

5) Kelima, segala unsur ikut saling menentukan dalam interaksi jaringan dan proses dalam interelasinya dengan bebagai aspek, tidak hanya sebagai oposisi biner (either-or) dengan dua sisi saja.

6) Keenam, segala hal harus dilihat secara holistik berbagai kemampuan (faculties) lain selain rasionalitas, misalnya, emosi, imajinasi, intuisi, spiritualitas, dan sebagainya.

7) Ketujuh, segala hal dan pengalaman yang selalu dimarginalisasi oleh pola ilmu pengetahuan modern dikembalikan ke tengah menjadi fream pemikiran 


\section{Aris Puji \& Hendri}

(Bertens, 2006: 88). Misalnya, gender, feminisme kaum perempuan, tradisi-tradisi lokal, paranormal, agama. Filantropi termasuk dalam bahasan agama dan tradisi sekaligus, oleh karena itu filantropi layak juga dikaji menggunakan perspektif postmodern.

\section{Sejarah term filantropi dalam Islam}

Filantropi termasuk salah satu penelitian dalam bidang ekonomi, karena dalam prinsip ekonomi disebutkan bahwa salah satu motif manusia melakukan kegiatan ekonomi adalah untuk mendapatkan pemasukan. Motif ekonomi menyebutkan bahwa salah satu tujuan manusia melakukan kegiatan ekonomi adalah untuk memenuhi keinginan pribadi yang lebih terlihat dalam keinginan untuk memenuhi semua kebutuhannya. Filantropi menjadi satu fenomena yang sulit diungkap melalui teori ekonomi, karena filantropi secara prinsip ekonomi tidak menghasilkan manfaat pada sisi ekonomi, malah sebaliknya cenderung mengurangi pendapatan.

Apabila dilihat secara difinitif, filantropi adalah the desire to promote the welfare of others, expressed especially by the generous donation of money to good causes (merriam-webster). Filantropi juga merupakan keinginan untuk membantu orang lain yang diwujudkan dengan amal sosial yang berupa uang atau sesuatu yang lain yang bisa membantu. Filantropi di Belanda tidak hanya berupa amal sosial dengan wujud uang, tapi bisa berupa donor darah bahkan donor organ tubuh bagi yang sudah meninggal (Bekkers, 2007: 349). Filantropi disebut dalam Alquran surat At-Taubah: 103 yang artinya: "Ambillah zakat dari sebagian harta mereka. Dengan zakat itu, kamu membersihkan dan mensucikan mereka, dan berdoalah untuk mereka. Sesungguhnya doamu itu (menjadi) ketenteraman jiwa bagi mereka. Dan, Allah Maha Mendengar lagi Maha Mengetahui." (QS. At-Taubah: 103) 
Filantropi lebih lanjut juga disebutkan dalam surat AlMa'un: 1-7 yan artinya: "Tahukah kamu (orang) yang mendustakan agama? Itulah orang yang menghardik anak yatim, dan tidak menganjurkan memberi makan orang miskin, (yaitu) orang yang lalai dari solatnya, orang-orang yang berbuat riya, dan enggan (menolong) dengan barang berguna". (QS. Al-Ma'un: 17)

Indonesia adalah negara dengan jumlah penduduk Muslim terbesar di dunia sekitar 87,2 persen dari total jumlah penduduk Indonesia (indonesia-investments). Tradisi berfilantropi bangsa ini telah ada sejak sebelum masa kemerdekaan, dan mencapai puncaknya saat perlawanan sengit terhadap penjajah (Bamualim, 2005: 6). Filantropi juga sudah menjadi salah satu budaya dalam masyarakat pedesaan pada masa lalu, menjadi salah satu tradisi yang sudah mengakar pada masyarakat pedesaan.

Perbuatan yang menunjukkan filantropi di pedesaan antara lain dengan sikap membantu teman, tetangga dan keluarga yang sedang mengalami kesulitan, keinginan dan meringankan beban kemiskinan (Saidi, dkk, 2006: 5). Menurut Ketua BAZNAS Bambang Sudibyo, potensi zakat Indonesia berdasarkan penelitian yang dilakukan oleh ITB pada tahun 2011, potensi zakat Indonesia berdasarkan PDB pada tahun 2010 adalah 217 triliun rupiah, dan meningkat menjadi 286 triliun rupiah pada tahun 2015. Namun realisasi penghimpunan masih rendah, yaitu 3,7 triliun pada tahun 2015 (http://ksp.go.id). Jumlah penduduk Provinsi Jawa Tengah pada tahun 2014 tercatat 33,52 juta jiwa, atau sekitar $13,29 \%$ dari total penduduk Indonesia (http://jateng.bps.go.id). Kota Semarang sebagai Ibukota Provinsi Jawa Tengah adalah Jumlah penduduk Kota Semarang tahun 2015 adalah 1.765 .396 jiwa (http://dispendukcapil.semarangkota.go.id). 


\section{Aris Puji \& Hendri}

Filantropi adalah keinginan untuk membantu orang lain yang diwujudkan dengan amal sosial yang berupa uang atau sesuatu yang lain yang bisa membantu. Joseph Wales, Monazza Aslam, Sebastiaen Hine, Shenila Rawal, Leni Wild (2015) menjelaskan bahwa filantropi dan charity adalah dua istilah yang tumpang tindih dalam pendefisiannya, karena memang dua hal ini merupakan satu irisan yang sama bertujuan untuk membantu orang lain agar lebih baik. Secara harfiah filantropi adalah niat dengan tujuan mendatangkan kebaikan manusia, sedangkan charity adalah empati dan perbuatan altruism atas kemalangan/penderitaan orang lain. Sedangkan altruism lebih bersifat menggebu dan tanpa pertimbangan. Persamaan filantropi dan charity lainnya adalah sama-sama merupakan konsep pemberian pribadi tanpa melibatkan atau melalui institusi Pemerintahan.

Definisi filantropi menurut Barat adalah tindakan sukarela untuk kepentingan publik. Sukarela adalah tindakan bebas yang bertujuan memberi, melayani, dan bergaul untuk masyarakat untuk mengurangi penderitaan, kekurangan, dengan memberikan kebutuhan dasar misalnya makan dan tempat tinggal, atau meningkatkan kehidupan orang yang diberi misalnya dengan pendidikan dan rekreasi. Secara tradisional, subjek dan objek filantropi adalah manusia dan kelompok manusia, meskipun pada masa selanjutnya makhluk dan lingkungan itu sendiri adalah objek yang menarik. Filantropi berasal dari Yunani Kuno antara abad V-VI digambarkan secara umum sebagai term filosofis dan teologis untuk menggambarkan keberagaman aktivitas manusia dalam artian bahwa manusia itu bisa melakukan banyak hal dalam kehidupannya.

Dokumentasi filantropi tertua yang bisa digunakan manusia adalah Academy Plato yang telah mengajarkan tentang filantropi, serta tindakan Plato yang mewariskan semua hartanya kepada penerusnya (successor) saat ia meninggal pada tahun 345 SM. Tradisi pewarisan ini terus 
berlangsung dan berakhir saat Philo of Larissa meninggal pada tahun 83 SM. Filantropi muncul lagi pada tahun $410 \mathrm{M}$ dan dihancurkan kembali pada tahun $529 \mathrm{M}$ oleh Justinian I. Perkembangan filantropi selanjutnya dilakukan oleh organisasi-organisasi kemasyarakatan (Cheek dkk, tt: 364).

\section{Filantropi pada masa Postmodern}

Filantropi yang pada awalnya hanya dilakukan oleh penguasa, kemudian popular menjadi amal masyarkat secara umum. Perkembangan filantropi pada abad ke-19 adalah salah satu dari kategori literal, kuno, ideal, ontologis, kehendak, sebenarnya dan sosial. Pada abad ke-20, istilah filantropi dipersempit sebagai wacana ilmiah dan penggunaan umum (bukan hanya istilah akademik), sebagai perbuatan memberi dan pengaruhnya. Definisi filantropi dalam wacana akademis saat ini dibagi menjadi 3 paradigma, yaitu:

1) Paradigma pertama, filantropi diartikan dengan pemberian sukarela/terserah kepada donor/pelaku filantropi. Sebagai contoh adalah dibunuhnya Spurius Maelius pada abad ke-4 SM oleh Pemerintahan saat itu karena dicurigai akan melakukan perbuatan subversive. Pada tahun 1930-an saat terjadi depresi besar-besaran, filantropi diberikan oleh perusahaanperusahaan dan bank, agar tidak didemo oleh masyarakat. Pada abad ke-20 istilah filantropi dicemooh masyarakat, namun walaupun banyak dikritik, namun sebenarnya tidak ada pemberian yang buruk. Selain itu pemberian filantropi ini bisa bermanfaat untuk kepentingan umum (Choi dan DiNitto, 2012).

2) Filantropi menurut paradigma kedua adalah perbuatan memberi yang bertujuan untuk memenuhi kebutuhan manusia dengan segera. Sebagai contoh adalah charity yang dilakukan Gubernur John 


\section{Aris Puji \& Hendri}

Winthrop pada tahun 1630. Dalam tradisi Yahudi, filantropi adalah pemberian penuh kasih yang berkaitan dengan konsep tzedakah (karya amal, keadilan), dan Tikkun Olam (perbaikan dunia). Dalam tradisi Kristen, filantropi berkaitan dengan konsep charitas (kasih yang terbatas untuk semua orang). Dalam perjanjian lama, bentuk filantropi adalah dengan memberikan 1/10 dari pendapatan seseorang. Perkembangan konsep filantropi dari waktu ke waktu mengalami perubahan, dari mulai sector non-profit, amal, sector independen, sector sukarela, LSM, filantropi dan usaha sosial (A Dictionary of Civil Society, Philanthropy and the Non-Profit Sector, 2005: 15). Perkembangan term ini sangat dipengaruhi oleh keragaman dan organisasi-organisasi yang berkembang di setiap Negara. Para ilmuwan sosial dan pembuat kebijakan pada awalnya tidak terlalu memperhatikan konsep seperti filantropi, kesukarelaan, modal usaha, masyarakat sipil dan organisasi-organisasi non-provit. Merke lebih focus terhadap ilmu-ilmu sosial dan kondisi pasar serta kebijakan pemerintah. Dalam tradisi Islam, filantropi bisa berupa zakat (menyumbangkan sebagian kecil dari kekayaan sebagai bentuk ibadah), pemberian penuh kasih adalah makna dari prinsip takaful (solidaritas sosial), sedekah (kebajikan), dan wakaf (Cheek dkk, tt: 365).

3) Filantropi menurut paradigma ketiga adalah tidak sekedar egoistic giving ataupun pemberian yang bertujuan mencukupi kebutuhan primer manusia, namun suatu amal yang secara sistematis diharapkan bisa meningkatkan kehidupan dan membina kehidupan manusia agar bisa mandiri. Wujud filantropi ini misalnya scientific giving, yaitu pemberian yang sudah bisa dihitung secara matematis 
dampak/kompensasi yang diharapkan. Namun jenis fiantopi ini biasanya hanya berhasil/cocok sesuai prediksi pada jenis pemberian obat-obatan, sedangkan pada pemberian jenis lainnya misalnya CSR, investasi social kurang cocok.

Kondisi seperti ini mulai berubah selama dua dekade terakhir abad ke-20. Sektor non-profit saat ini telah menjadi kekuatan ekonomi dan sosial yang besar (Singer. 2008: 15). Filantropi dalam budaya Barat bisa ditelusuri pada era pencerahan yang mulai berkembang filantropi rasional, artinya tidak hanya sekedar memberi, tapi memperhitungkan bagaiman efek dari pemberian itu. Filantropi adalah usaha yang lebih mengutamakan efek pemberian secara keseluruhan, bukan hanya dampak yang bisa dihitung secara ekonomis. Berangkat dari paradigma tentang filantropi di atas, teknis filantropi yang terdapat di berbagai Negara bervariasi yang dipengaruhi oleh faktor historis, sosial politik, budaya, geografis dan lainnya (A. List. 2011: 15).

Menurut Joseph Wales, Monazza Aslam, Sebastiaen Hine, Shenila Rawal, Leni Wild (2015), negara-negara di Eropa Barat memperluas filantropi sebagai amal yang dilakukan oleh serikat buruh, partai politik dan lembaga sosial resmi agar bisa memberikan dukungan sosial dan hakhak dasar kebutuhan hidup. Filantropi juga bisa berupa penyediaan sarana sosial, perumahan, pendidikan, dan pelayanan sosial oleh swasta dan Pemerintah sebagai kompensasi kenaikan pajak. Filantropi di Swedia dikoordinir dengan baik oleh Negara, kesejahteraan masyarakat dijamin dengan baik oleh Negara, namun masih ada yang melakukan filantropi secara pribadi. Realitas filantropi dari insentif pajak di German dan USA besarnya tetap kurang sebanding dengan besaran pajak yang dibayarkan. 


\section{Aris Puji \& Hendri}

Konsep yang mendekati filantropi saat ini adalah social capital. Secara umum adalah hubungan sosial yang baik antar individu atau kelompok masyarakat yang berpengaruh positif terhadap personal maupun kelompok masyarakat. Penggunaan istialah filantropi secara lebih luas dalam dunia akademik dimualai pada tahun 1950 -an. Hasil penelitian saat ini mengidentifikasi konsekwensi positif dan negative dari social capital. Konsekwensi positif tersebut misalnya pendidikan yang lebih baik, kesejahteraan anak yang lebih baik, lingkungan yang aman dan produktif, kesehatan yang lebih baik, kebahagiaan, kemakmuran ekonomi, demokrasi yang lebih baik, tatanan sosial dan dukungan sosial. Konsekwensi negatif dari social capital adalah anggota social capital terkadang harus mengeluarkan biaya lebih, karena seperti dipaksa untuk berfilantropi, terkadang dalam bersosialisasi. Sesama anggota harus "melanggar" norma sosial, misalnya boros, eksklusif, bahkan komunitas suatu social capital terkadang malah jauh dari lingkungan sosial sesungguhnya.

Konsep filantropi pada saat ini yang lain adalah nonprofit sector (usaha nir-laba). Pelaku kegiatan ini bisa dilakukan oleh sector formal dan non-formal yang tidak berorientasi pada keuntungan, sehingga pemilik dan investor tidak akan mendapatkan keuntungan secara material. Filantropi dalam arti lebih luas juga termasuk membangun masyarkata sebagai sarana untuk menciptakan modal sosial.

\section{Filantropi dalam perspektif global}

Penelitian yang dilakukan oleh Salamon dan Anheier (dalam Cheek dkk) menjelaskan bahwa pemahaman filantropi, masyarakat sipil, dan sektor nir-laba dalam perspektif global mengalami pertumbuhan. Kesulitan dalam penelitian tentang filantropi ini adalah adanya perbedaan tentang konsep filantropi itu sendiri, karena adanya perbedaan budaya, hukum, perbedaan jumlah dan kualitas 
data yang tersedia, risiko perhitungan ganda, perbedaan dalam paritas daya beli, dan skala serta biaya sebuah studi global. Sebagian besar penelitian yang dilakukan adalah meneliti filantropi sebagai lembagan on-profit, karena sebagian besar filantropi yang ada di Negara-negara Eropa seperti Swedia, Belgia, dan Negara-negara Anglo-Saxon (Inggris, Irlandia, USA dan Australia) adalah lembaga nonprofit.

Pada level Internasional, beberapa dekade terakhir ini telah bermunculan masyarakat sipil global dan organisasi non-profit transnasional dengan ukuran yang signifikan dan struktur organisasi yang kompleks yang semakin menjangkau banyak Negara dan benua. Salah satu contoh adalah Amnesty Internasional yang beranggotakan lebih dari 1 juta anggota, pelanggan donator lebih dari 140 Negara dan wilayah. Friends of The Earth Federation yang memiliki 1 juta anggota dan sekitar 5000 kelompok-kelompok lokal. The Coalition Against Child Soldiers membentuk mitra dan koalisi Nasional yang bergerak dalam advokasi, kampanye dan pendidikan publik hampir di 40 Negara. Care Internasioanal yaitu LSM Internasioanal yang memiliki lebih dari 10.000 staf professional, di USA memiliki omset sekitar US \$ 4500 miliyar. The International Union for the Concervation of Nature menyatukan 735 LSM, 35 afiliasi, 78 Negara, 112 Badan Pemerintahan, sekitar 10.000 ilmuwan dan ahli dari 181 Negara dalam kemitraan dunia yang unik (Midgley, 2009).

Berdasarkan data di atas, menunjukkan bahwa filantropi sebagai organisasi non-profit adalah bagian dari transformasi masyarakat industry ke neo-masyarakat industry, dari Negara menjadi mendunia, bahkan menjadi masyarakat ekonomi global. Pada awal abak ke-21 mulai bermunculan non-profit organisasi yang memberikan pengaruh terhadap sisitem kelembagaan Negara dan bisnis yang sebelumnya semua sektor publik untuk mendapatkan 


\section{Aris Puji \& Hendri}

keuntungan atau diatur Negara, namun saat ini bersifat sukarela dan pribadi. Eksistensi organisasi non-profit sebagai bagian integral dari perkembangan sosial, ekonomi dan politik di banyak Negara, mulai dari Negara-negara berkembang di Amerika Utara, Eropa dan Jepang, diakui juga dalam ekonomi transisi dari Eropa Tengah dan Timur, namun sampai di Negara-negara berkembang di Afrika, Asia dan Amerika Latin.

Filantropi sebagai non-profit sektor menjadi civil society pada tingkat local dan Internasional pada awal abad ke-21 karena didorong oleh permintaan pelayanan sosial kebutuhan manusia, reformasi kesejahteraan dan privatisasi kebijakan, penyebaran demokrasi dan kemajuan dalam teknologi informasi dan komunikasi. Penelitian dalam bidang ini sudah berkembang signifikan saat ini, namun pemahaman kita tentang lembaga-lembaga ini masih terbatas, jangkauan data sering tambal sulam, sedangkan teori lembaga non-profit yang dikembangkan saat ini sebagian besar dalam bidang ekonomi dan teori organisasi, sedangkat saat ini, modal sosial dan pendekatan masyarakat sipil telah memperluas bidang penelitian, sehingga dibutuhkan kontribusi dari sosiolog dan ilmu politik (Hoefer dan Midgley, 2006).

Sektor non-profit menjadi sesauatu yang belum dieksplore para pembuat kebijakan pada masa lalu, namun saat ini menjadi fokus kebijakan utama, sehingga secara tidak langsung akan mempengaruhi ikut berkembangnya lembaga-lembaga non-profit ini. Perkembangan filantropi sebagai lembaga non-profit menjadi suatu yang harus dipertimbangkan oleh suatu Negara, karena jika perkembangan lembaga non-profit ini terlalu pesat akan mengurangi peran Negara dalam meningkatkan kesejahteraan warganya, sehingga mau tidak mau, Negara harus bekerjasama dengan lembaga non-profit ini. Kebijakan 
ini diambil oleh Negara Amerika, Israel, Eropa Tengah, Eropa Timur dan Australia (Midgley, 2009).

Menurut Helmut K. Anheier and Regina A. List (2005: 26) benda-benda seperti baju, makanan, dan uang termasuk sesuatu yang bisa diberikan untuk orang-orang miskin. Pemberian seperti ini adalah bagian terpenting dari beberapa ajaran Agama, termasuk Kristen yang biasa disebut dengan istilah charity, Islam yang biasa disebut zakat, dan Yahudi yang biasa disebut sedekah. Agus Comte, sosiolog dan filosof dari Perancis pertengahan abad ke-19, mendefinisikan altruism sebagai lawan dari kata memuaskan diri, memaksimalkan utilitas dalam teori ekonomi. Secara harfiah, altruism didefinisikan sebagai untuk orang lain. Altruism adalah perilaku yang bertujuan untuk menguntungkan orang lain dengan tanpa memikirkan akibat dan hasilnya, dengan kata lain seperti rasa ingin merasakan penderitaan orang lain sehingga dengan cara apapun ingin membantu orang lain agar bisa keluar dari kesulitannya. Rasa ini murni tumbuh dari dalam hati, tidak ada pengaruh dari orang lain atau nilai-nilai tertentu. Altruism bersifat personal dan tanpa melalui lembaga non-profit.

\section{Simpulan}

Postmodern adalah teori yang pada awalnya ingin memperjelas dan menyempurnakan modern-theory, tetapi akhirnya malah merusak tatanan yang sudah ada. Postmodern hadir dengan paradigma bahwa sesuatu harus clear/jelas, termasuk hal-hal yang sebenarnya tidak perlu penjelasan. Postmodern menganut kebenaran yang plural, berbeda dalam teori modern yang sudah baku kebenarannya, berupa kebenaran tunggal. Salah satu alasan muculnya gerakan postmodernisme adalah dikarenakan persoalan yang menyangkut segala hal dan pengalaman yang selalu dimarginalisasi oleh pola ilmu pengetahuan modern 


\section{Aris Puji \& Hendri}

dikembalikan ke tengah menjadi frame pemikiran. Contohnya ialah tradisi-tradisi lokal, agama yang merupakan kombinasi dari praktik filantropi di masa kini.

Filantropi yang pada awalnya adalah cara para penguasa saat itu untuk tetap menjaga stabilitas keamanan masyarakat dengan memberikan bantuan kepada masyarakat, namun pada masa postmodern berubah menjadi badan-badan atau lembaga-lembaga sosial non-profit yang berfungsi menjadi mediator dari para donor kepada yang membutuhkan. Filantropi yang pada awalnya hanya berupa barang-barang yang bertujuan untuk meringankan dan memenuhi kebutuhan masyarakat yang kekurangan, pada era postmodern bisa berkembang menjadi donor bagian tubuh, senyum dan bahkan empati sudah bisa disebut sebagai filantropi. Sedekah yang pada awalnya berupa barang-barang kebutuhan manusia, pada postmodern diperluas bahwa menyebarkan ilmu pengetahuan, menggerakkan masyarkat juga bisa disebut filantropi.

\section{Daftar Pustaka}

A. List, John. "The Market for Charitable Giving". dalam Journal of Economic Perspectives. Vol. 25. Number. 2, 2011.

Ahimsa Putra, Heddy Shri. "Poststrukturalisme dan Postmodernisme". Akademia, Bogor, 2005.

Anheier, Helmut K. and Regina A. List. A Dictionary of Civil Society, Philanthropy and the Non-Profit Sector. Routledge, London and New York, 2005.

Baramulim, Chaider S dan Irfan Abu Bakar. Lembaga Zakat dan Wakaf di Indonesia. Pusat Bahasa dan Budaya UIN Syarif Hidayatullah, Jakarta, 2005. 


\section{Histori Filantropi: Tinjauan Teori ...}

- Islamic Philanthropy $\mathcal{E}$ Sosial Development in Contemporary Indonesia. Center for Study of Religion and Cultur (CSRC) UIN Syarif Hidayatullah, Jakarta, 2006.

Bauman, Zigmunt. Postmodernity and Its Discontents, Polity Press, London, 1997.

Bekkers, Rene. Science of Generosity Generosity and Philanthropy: A Literature Review, Pamala Wiepking, Department of Philanthropic Studies. Vrije Universiteit Amsterdam, Amsterdam, 2007.

Bertens, Hans. The Idea of the Postmodern". Taylor \& Francis e-Library, Prancis, 2005.

Dennis W. Cheek \& Michal Kramarek and Patrick Rooney, Charity and Philanthropy: Overview. Elsevier Ltd.Versus Charity, Jones and Bartlett Publisherr, LLC, diakses dari

http:/ / samples.jbpub.com/9780763766788/66788_C H01_ Dietlin.pdf, diakses pada tanggal 19/07/2018.

Gardner, Katy dan David Lewis. Anthropology, Development and the Postmodern Challenge. Pluto Press, USA, 1996.

Harbaugh, William T. "What do Donations Buy? A Model of Philanthropy Based On Prestige and Warm Glow" dalam Journal of Public Economics. 67, 1998.

Hearn, Mark. "Interprating Postmodernity". Artikel. http:/ / www.interpretingpost modernity.net/hearn_interpreting_postmodernity.pd f diakses tanggal 24/04/2017.

Hoefer, Richard dan James Midgley. International Perspectives on Welfare to Work Policy. Routledge, USA, 2007.

http://dispendukcapil.semarangkota.go.id. diakses pada tanggal 19/07/2018. 


\section{Aris Puji \& Hendri}

http://jateng.bps.go.id. diakses pada tanggal 19/07/2018.

http://ksp.go.id. diakses pada tanggal 19/07/2018.

James Midgley. Social Policy and Poverty in East Asia the Role of Social Security. Routledge, USA, 2009.

Joseph Wales, Monazza Aslam, Sebastiaen Hine, Shenila Rawal, Leni Wild. The Role and Impact of Philanthropic and Religious School in Developing Countries. University of Birmingham, Birmingham, 2015.

Lubis, Akhyar Yusuf. Masih Adakah Tempat Berpijak Bagi Ilmuwan. Akademia, Bogor, 2004. . Postmodernisme: Teori Dan Metode. PT Raja Grafindo Persada, Jakarta, 2014.

Namkee G. Choi \& Diana M. DiNitto. "Predictors of Time Volunteering, Religious Giving, and Secular Giving: Implications for Nonprofit Organizations". dalam Journal of Sociology \& Social Welfare. Vol. XXXIX, Number 2, 2012.

Rosenau, Pauline. Post-Modernism and the Social Sciences. Princeton University Press, New Jersey, 1992.

Saidi, Zaim dkk. Kedermawanan Untuk Keadilan Sosial. Piramedia, Jakarta, 2006.

Singer, Amy. Charity in Islamic Societies. Cambridge University Press, London, 2008.

Turner, Tom. City as Landscape (a Post-Postmodern View of Design and Palnning). E\&FN Spon, an imprint of Chapman \& Hall, London, 1996. 